\title{
Measuring competencies of higher education graduates
}

Citation for published version (APA):

Allen, J. P., Ramaekers, G. W. M., \& van der Velden, R. K. W. (2005). Measuring competencies of higher education graduates. New Directions for Institutional Research, 126, 49-59. https://doi.org/10.1002/ir.147

Document status and date:

Published: 01/01/2005

DOI:

10.1002/ir.147

Document Version:

Publisher's PDF, also known as Version of record

\section{Please check the document version of this publication:}

- A submitted manuscript is the version of the article upon submission and before peer-review. There can be important differences between the submitted version and the official published version of record.

People interested in the research are advised to contact the author for the final version of the publication, or visit the DOI to the publisher's website.

- The final author version and the galley proof are versions of the publication after peer review.

- The final published version features the final layout of the paper including the volume, issue and page numbers.

Link to publication

\footnotetext{
General rights rights.

- You may freely distribute the URL identifying the publication in the public portal. please follow below link for the End User Agreement:

www.umlib.nl/taverne-license

Take down policy

If you believe that this document breaches copyright please contact us at:

repository@maastrichtuniversity.nl

providing details and we will investigate your claim.
}

Copyright and moral rights for the publications made accessible in the public portal are retained by the authors and/or other copyright owners and it is a condition of accessing publications that users recognise and abide by the legal requirements associated with these

- Users may download and print one copy of any publication from the public portal for the purpose of private study or research.

- You may not further distribute the material or use it for any profit-making activity or commercial gain

If the publication is distributed under the terms of Article $25 \mathrm{fa}$ of the Dutch Copyright Act, indicated by the "Taverne" license above, 
This chapter describes a new conceptual model for measuring competencies of higher education graduates. The proposed instrument can become a valuable tool for higher education quality management, policy evaluation, and scientific research.

\title{
Measuring Competencies of Higher Education Graduates
}

\author{
Jim Allen, Ger Ramaekers, Rolf van der Velden
}

In this chapter, we take the first step toward developing a new conceptual model for measuring competencies of higher education graduates. Before outlining the model, we first look into the main reasons for needing information about higher education graduates' competencies. Subsequently, we present a brief sketch of some important theoretical and empirical work on the nature and importance of different kinds of competencies. We then outline the basic elements of the model and provide a brief description of how the data generated by our research instrument can be used in practice. Since this new model is a work in progress, we conclude with some reflections of what still needs to be done to make the new approach practical and useful to those concerned with graduates' competencies.

\section{Why Measure Competencies?}

A recent publication by the Education Council of the Netherlands (Onderwijsraad, 2002) sketches the emerging interest in competencies in the Netherlands in recent decades from the perspective of both the labor market and higher education. In the 1970s, Dutch firms placed great emphasis on standardization of work processes and a strong division of labor. Under the influence of the human relations approach in the United States, there was some interest in the employee as a learning individual, but this was arguably more motivated by the desire to promote employees' self-development and 
commitment to the firm than by the desire to directly influence their performance and productivity.

In the 1980s, more attention was paid to product quality and differentiated customer demand, and consequently, separate training departments in firms became commonplace. However, because of the high costs of private training, the teaching of initial vocational skills was delegated as much as possible to state-funded vocational education, which experienced an enormous expansion in this period. This expansion gave rise to concerns about the extent to which the vocational education sector was equipped to deal with the demands that were being thrust on it. The ensuing debates revolved around a discussion about whether schools should aim to improve the instrumental qualifications or direct capacities of school leavers (graduates) or instead develop graduates' ability to adapt to the changing nature of the labor market (see Van Hoof and Dronkers, 1980). Due to the strong pressure from employers, the prevailing view in this period was that the link between education and labor market could best be improved by placing more emphasis on technical-instrumental qualifications.

Despite these discussions, there was still relatively little attention given to the concept of competencies until the start of the 1990s. This concept gained strength with the appearance of an influential publication on core competencies by Prahalad and Hamel (1990). Since then, the concept of competencies has been dominant in Dutch firms and organizations, and the Dutch economy has increasingly been perceived as a knowledge economy. In the debate on education and curricula, the pendulum shifted more toward a need for flexibility (Van Zolingen, 1995), as it was felt by many that a direct translation of demands from the labor market into educational curricula was undesirable and in fact not realizable. The increasing popularity of this viewpoint appears to be related to the volatility and apparent unpredictability of the labor market in that period.

The concept of key qualifications, developed in the 1970s in Germany by Mertens (1974), was introduced around this time to the discussion in the Netherlands (Van Zolingen, 1995). The key qualifications concept focuses on the knowledge, skills, and attitudes needed for flexible performance within a particular occupational domain. Toward the end of the 1990s, this concept made way for the concept of competencies, regarded as learnable and teachable attributes that indicate aptitude to perform various human activities such as work, learning, and coping with change.

This period also witnessed the demise of the notion of higher education as an autonomous regime. Higher education increasingly came to be seen as the provider of intellectual capital for the knowledge economy, whereby the main emphasis was placed on competencies related to teamwork, problem solving, creativity, and analytical abilities. These competencies were seen as characteristics of competent and broadly employable graduates. 


\section{Quality Management}

Not surprisingly, the increased interest in competencies and the relevance of education for the labor market has not gone unnoticed by those concerned with quality management in higher education. In the past, the focus was mainly on educational inputs and the educational process itself, but today there is increased attention to the final goals, or desired outputs, of higher education courses. There has also been a further shift within the outputs, from educational performance as indicated, for example, by exam results, to the competencies that graduates (are expected to) possess. The reasoning is simple: the proof of the pudding is in the eating, and higher education courses can best demonstrate their quality through the ability of their graduates to perform in practice.

These shifts are clearly visible in the recent discussions concerning the introduction of a system of accreditation for higher education courses. A central question, then, is to what extent courses succeed in providing their graduates with the qualifications needed to make a good start in the labor market. This discussion has focused strongly on the formulation of the main underlying dimensions of these qualifications-the so-called final goals of the various types of higher education courses-and how these can best be operationalized. These final goals are explicitly formulated in terms of the capacities of graduates to perform in practical situations and applying and building on knowledge gained in higher education. An important implication of this is that competencies, as well as possible deficiencies or surpluses, cannot be measured in isolation from the practical work situation that graduates experience after graduation (Ramaekers, Van Eijs, and van der Velden, 2003).

\section{Theoretical Framework for Measuring Competencies}

Competencies acquired in education are necessary not only for ensuring quick productivity returns on initial entry to the labor market but also for employability in the long term. It is important to gain insight into the role of various kinds of competencies in the short and long terms and to the extent to which courses in higher education offer the right mix of these competencies, given the goals and needs of employers and employees in the labor market. To achieve this, we need to delve into the literature concerning specific and general competencies.

Specific Competencies. Specific competencies refer to clusters of cognitive prerequisites that an individual requires in order to be able to perform adequately in a given substantive area (Weinert, 2001). Simple examples are skills required for flying an airplane or making a medical diagnosis. Specific competencies can offer strong productivity gains in the short term. Graduates already capable of performing many of the specialized tasks 
associated with certain jobs need less on-the-job training before they can work effectively, and such specialized skills are highly productive when applied appropriately. However, due to changes in technology and shifts in labor demand, specific competencies are often prone to lose value over time.

General Competencies. The label of "general competencies" in fact covers a diversity of concepts, such as intelligence, information-processing models, meta-competencies, and key competencies. The common element of these concepts is that they can be applied in a range of contexts and contents. It is for this reason that such competencies are viewed as important for long-term employability. Some general competencies are thought to contribute directly to productivity in a range of contexts; others are expected to help individuals in transferring existing specific competencies and acquiring new specific competencies needed in new work situations.

Integrated Approaches. The context-dependent character of specific competencies makes them concrete and relatively easy to measure but renders them unsuitable for broad comparisons. General competencies lend themselves well for comparison across a wide range of contexts, but are often rather abstract, ambiguous, and difficult to measure.

There have been a number of attempts to integrate specific and general competencies into a more general framework. For example, Bloom (1956) distinguished six levels of competencies, ranging from entirely contextspecific competencies to entirely context-neutral competencies. Action competence models (for example, Boyatzis, 1982; Lévy-Leboyer, 1996) also often comprise both general and specific components and strive to incorporate all those cognitive, motivational, and social requirements for successful learning and action. However, none of these approaches has been developed specifically for the purpose of evaluating the quality of a wide range of higher education courses. With this general goal in mind, in the next section we sketch the contours of a new model for measuring graduate competencies.

\section{Contours of a New Conceptual Model}

At the risk of stating the obvious, competencies are what make people competent. They should therefore be defined as prerequisites for effective action. For our purposes, they should cover nearly the full range of graduate competencies, taking into account all the general and specific knowledge, skills, and motivations that may be needed for effective action. The competencies should have a uniform meaning across a range of contexts. In the rest of this chapter, we refer to such competencies as meaning context-neutral action competencies.

Competent for What? The general definition does not in itself tell us what particular competencies need to be measured, and the literature on competencies does not provide a ready-made list. As an intermediate step, we ask about the purposes for these competencies. What kinds of actions are higher graduates called on to carry out? Quinn, Faerman, Thompson, and 
McGrath (1990) have developed a classification of five necessary functions belonging to eight different roles of managers and have identified the key competencies required for each function and role. Loosely based on their work, we distinguish nine broad action categories that we regard as relevant to the work situations in which all categories of higher education graduates may find themselves: directing productive tasks, directing the work of others, planning, coordination, control, innovation, information management, maintaining relations with personnel, and maintaining relations with clients.

Deriving the Competencies. The relevant competencies can be derived by asking what kinds of knowledge, skills, and motivations are likely to be performed. In most cases, several competencies are required for a particular action category. For example, for successful information management, a person needs to be capable of conveying ideas and information clearly to others, but may also need to be good at picking up signals from others and selecting which information is relevant for communication. Similarly, directing productive tasks may require field-specific knowledge, an ability to work without supervision, and an ability to take decisive action.

Conversely, different competencies can also underlie several different actions. For example, some competencies used for directing the work of others may also overlap with those required in planning, coordination, and information management. In practice, the competencies required to perform a given action, and the kinds of action a given competency is used for, will vary from person to person and from situation to situation. Nonetheless, it is possible to draw up a matrix consisting of the action categories and the competencies that are likely to be needed to perform them in a typical work situation. Such a matrix is shown in Figure 4.1.

What We Need to Know About Competencies. In our view, it is appropriate to measure both available and required competencies. Available competencies - those that graduates actually possess - provide the most direct information possible in terms of the productive potential of higher education graduates. In order to gain a view of the minimum level needed by all graduates in order to perform adequately in the labor market and the competencies that need to be mastered at a higher level for given courses, it is also important to measure required competencies. A comparison between actual and required competencies can shed light on shortages and surpluses.

Competencies can be measured at the time of graduation or some time after the transition to the labor market. In theory, competencies at the moment of graduation are more reflective of the actual output of courses. However, since competencies are supposed to reflect graduates' ability to function in practice, it is desirable that they have already gained some practical work experience. Moreover, if we wish to compare actual competencies with those required in the labor market in order to calculate shortages and surpluses, both questions should refer to the same moment in time. For this reason, both questions refer to the situation at the time of the survey. This has the added advantage of not overtaxing the respondents' memories. 


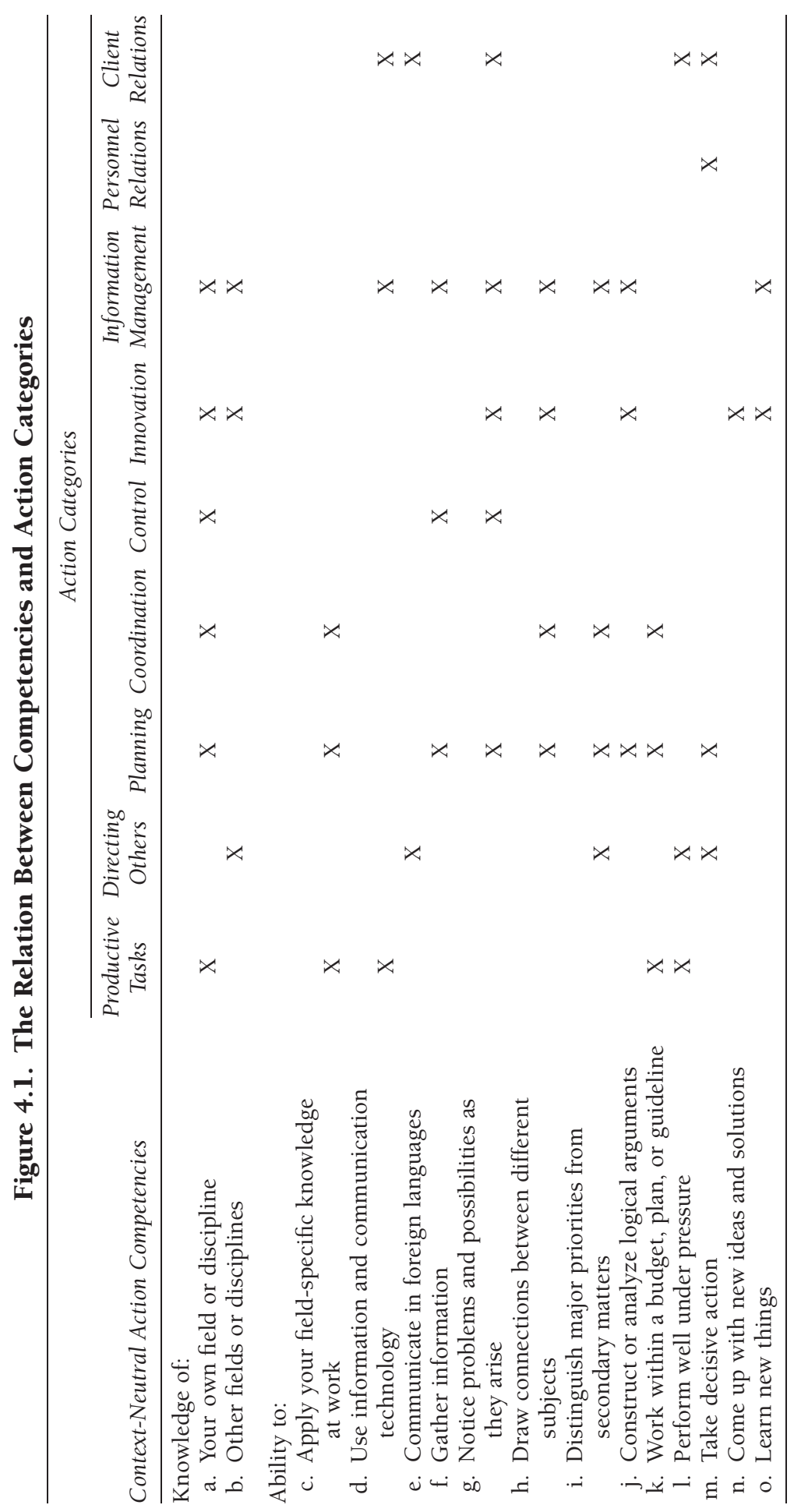




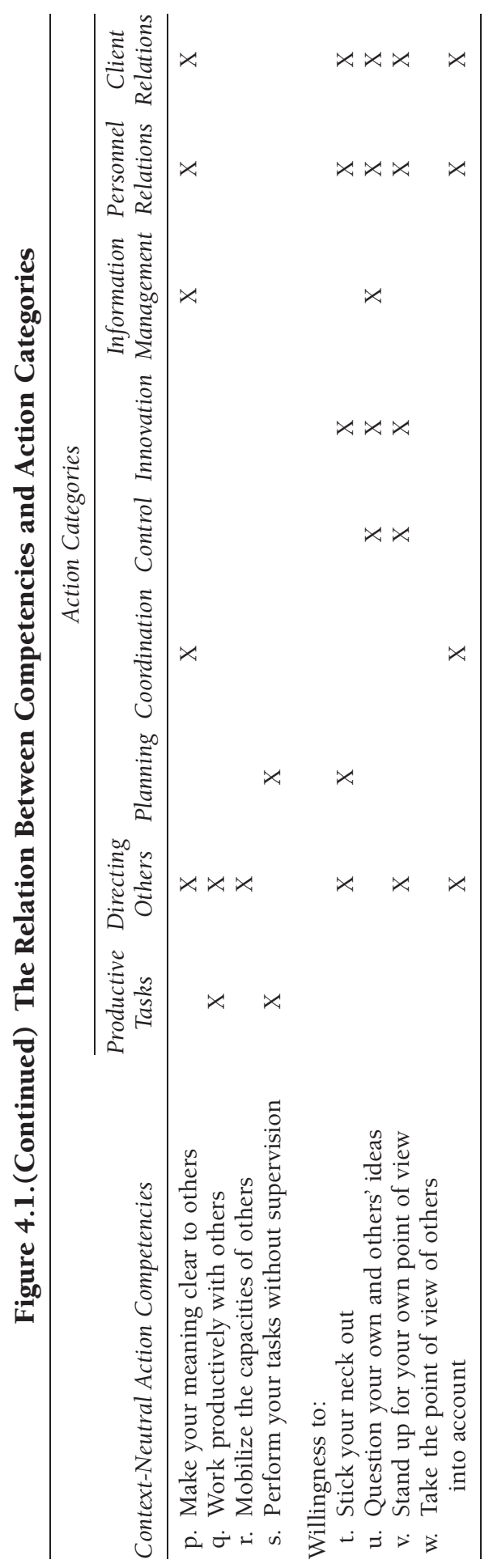




\section{Using the Instrument}

Data on competencies that are collected using the proposed instrument can be used by several categories of users in many ways. First, comparative feedback can be provided to higher education institutions indicating how the competencies possessed by their graduates measure up to graduates from other institutions. Several frames of reference are relevant here. First, the main focus for those responsible for curriculum evaluation and quality control is at the level of a particular course. The feedback given can allow quality controllers to assess the relative strengths and weaknesses of their own graduates' competencies compared to those of graduates of equivalent courses offered by other institutions. This should involve more than simply comparing means for the various competencies across different institutions. Some institutions may seek to occupy a niche in their particular market and deliberately place more or less emphasis on generating certain competencies than other institutions offering an equivalent course. It is important to take this into account when interpreting the results: a lower score than other institutions on certain competencies is not necessarily an indication of lower quality; it may instead reflect deliberate educational choices.

The feedback given should also allow broad comparisons among different higher education courses. In contrast to comparisons between institutions offering an equivalent course, whereby both general and specific competencies can be compared, comparisons among different types of courses are possible only for general competencies and abstract measures of specific competencies. However, even general competencies, such as analytical, social, and management skills, may be quite deliberately more or less emphasized in different types of higher education course. It is therefore of great importance to take such differences into account when interpreting the results.

A good way to ensure that such differences in emphasis are kept firmly in view is to compare the competencies graduates possess with those required in the jobs they occupy after graduation. More generally, such a comparison offers a good way of checking the labor market relevance of graduates' competencies. For courses designed to prepare graduates for a particular occupation or range of occupations, the primary focus will be on the actual and required competencies of those whose work is closely related to their field of study. For courses intended to prepare graduates for a wider range of occupations, it is important to compare actual and required competencies not only for those whose work is closely related to their study, but also for those working in very different fields. This can indicate whether graduates possess the competencies needed for broader employability.

Provided that the results are presented and interpreted in a sufficiently differentiated manner, the items that make up our proposed instrument are well suited for the purposes of improving course curricula and design. For example, where more traditional lists may reveal a shortage of leadership 
skills, our instrument distinguishes between underlying aspects that may be important for leadership in different situations, such as decisiveness, the ability to mobilize the capacities of others, or the ability to work according to a plan or budget. Not all graduates who are low on the category of "leadership skills" necessarily lack all these underlying competencies in equal measure. Similarly, not all these competencies are necessarily required in equal measure to provide successful leadership in jobs held by graduates of a particular course. Such items therefore allow a more targeted response in reforming curriculum or course design. Such information can also play an important role in accrediting higher education courses.

The proposed instrument can be used to evaluate policy initiatives such as the introduction of a comparable system of bachelor's- and master's-level courses in higher education throughout Europe. Unlike internal indicators such as exam results, the meaning of competencies does not change as a result of the system change. Unlike other external indicators such as unemployment rates and wage levels, competencies also do not depend on the current state of the labor market to provide meaning. Of course, the nature of work may change over time, so that even if competencies have remained constant, their relevance may have changed. By including required competencies as well as the competencies possessed by higher education graduates in the instrument, shifts in both actual and required competencies, and in the accompanying shortages and surpluses of particular competencies, can be tracked. By focusing on specific groups of graduates, it is possible to localize the areas in which the policy change has worked better or worse in terms of both professional expertise within one's own domain and flexibility and employability outside one's own domain. The outcomes of such analyses can be made available to various interested parties, such as policymakers, higher education institutions, national associations, (prospective) students, graduates, and employers. The results can be made available through public reports and over the Internet.

Finally, the data on graduate competencies can be made available to scientific researchers interested in understanding the workings of the graduate labor market. Compared to more conventional data on the transition from study to work, information on competencies offers real insights into the processes by which graduates are selected, allocated, and rewarded in the labor market. By including data on actual and required competencies, light can be shed on many interesting and topical debates. For example, does "overeducation" necessarily lead to mismatches between actual and required competencies? Are graduates who get "good" jobs more competent than similarly educated graduates who get less impressive jobs, and if so, can particular competencies be pinpointed? Do graduates with different educational backgrounds who work in the same occupations have similar competency profiles? Such questions are not only of scientific interest, but are of great interest to higher education policymakers concerned with graduate employment. 


\section{Further Elaboration of the Proposed Research Program}

The model we have outlined is still very much a work in progress. Research is needed in order to improve and refine the instrument and its use in assessing higher education quality. It is essential that detailed elaboration take place in close collaboration with relevant experts in the fields of higher education and competency research. Through discussions with these experts, it can be established whether the concept of context-neutral action competencies is appropriate to the goals pursued, if the current list is complete, and whether the formulations need major adjustments or just finetuning. It is also important to further explore the relationship between the dimensions or action categories and the competencies themselves.

For various reasons, a large part of actual competency development takes place not during the course of earning a degree but during one's career. One reason for this phenomenon is the uncertainty of how specific competencies will be used in the future. In some cases, for example, the competencies in question are difficult, if not impossible, to learn in a classroom setting and need to be learned in practice. Some skills can be learned only after a sufficient foundation of more basic competencies has been laid, and many regard the development of these basic competencies as the true function of higher education (Bartel and Sicherman, 1998). In order to determine which competencies can better be learned in education and which can better be learned at work, it is important to study the ways in which the various kinds of competencies are related to one another in their development and application.

\section{References}

Bartel, A. P., and Sicherman, N. "Technological Change and the Skill Acquisition of Young Workers." Journal of Labor Economics, 1998, 16(4), 718-755.

Bloom, B. S. (ed.). Taxonomy of Educational Objectives. Handbook I: Cognitive Domain. New York: McKay, 1956.

Boyatzis, R. E. The Competent Manager: A Model for Effective Performance. New York: Wiley, 1982.

Lévy-Leboyer, C. La Gestion des Compétences. Paris: Les Editions d'Organisation, 1996.

Mertens, D. "Schlüsselqualifikationen. Thesen zur Schulung einer Mondernen Gesselschaft." Mitteilungen aus der Arbeitsmarkt- und Berufsforschung, 1974, 7, 314-325.

Onderwijsraad. Competenties: Van Complicaties tot Compromis. Over Schuifjes en Begrenzers. Den Haag: Onderwijsraad, 2002.

Prahalad, C. K., and Hamel, G. "The Core Competence of the Corporation." Harvard Business Review, May-June 1990, pp. 79-91.

Quinn, R. E., Faerman, S. R., Thompson, M. P., and McGrath, M. Becoming a Master Manager: A Competence Framework. New York: Wiley, 1990.

Ramaekers, G., Van Eijs, P., and van der Velden, R. Kwaliteitsbeoordeling van Hoger Onderwijs. Maastricht: Researchcentrum voor Onderwijs en Arbeidsmarkt, 2003.

Van Hoof, J. J., and Dronkers, J. Onderwijs en Arbeidsmarkt: een Verkenning van de Relatie Tussen Onderwijs, Arbeidsmarkt en Arbeidssysteem. Deventer: Van Loghum Slaterus, 1980. 
Van Zolingen, S. J. "Gevraagd: sleutelkwalificaties. Een Studie Naar Sleutelkwalificaties Voor Het Middelbaar Beroepsonderwijs.” Academisch Proefschrift. Nijmegen: Katholieke Universiteit Nijmegen, 1995.

Weinert, F. E. "Concept of Competence: A Conceptual Clarification." In D. S. Rychen and L. H. Salganik (eds.), Defining and Selecting Key Competencies. Seattle, Wash.: Hofgrefe \& Huber, 2001.

JIM ALLEN is a project manager in the Education and Occupational Career Division at the Research Centre for Education and the Labour Market, Maastricht University, The Netherlands.

GER RAMAEKERS is a project manager in the Education and Occupational Career Division at the Research Centre for Education and the Labour Market, Maastricht University, The Netherlands.

ROLF VAN DER VELDEN is head of the Education and Occupational Career Division at the Research Centre for Education and the Labour Market, Maastricht University, The Netherlands. 